\title{
異なる運動肢位における肩外旋運動時の筋活動動態
}

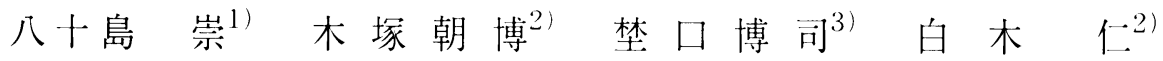 \\ 向 井直 樹 $^{2}$ 下條任 士2) 宮 永 豊 $^{2}$
}

\section{ELECTROMYOGRAPHIC ACTIVITY OF SHOULDER MUSCLE AT DIFFERENT POSITIONS DURING EXTERNAL ROTATION}

\author{
Takashi Yasojina, Tomohiro Kizlka, Hikoshi Noguchi, Hitoshi Shiraki, \\ Naoki Mlikal, Hitoshi Shimojo and Yutaka Miyanalia
}

\begin{abstract}
Electromyographic activity of the shoulder muscle at 2() and 90 abduction (20 Abd, $90 \mathrm{Abd}$ ) during external rotation was investigated in seven healthy men with no history of injury or instabil. ity of the shoulder joint.

Electromyography (EMG) was recorded using intramuscular fine-wire electrodes inserted into the M. Supraspinatus, M. Infraspinatus and M. Teres minor, and with bipolar surface electrodes on the middle and posterior parts of $\mathrm{M}$. Deltoid and the upper and middle parts of $\mathrm{M}$. Trapezius. To compare activity in different muscles, the integrated EMG (iEMG) activity of each muscle was normalized.

M. Infraspinatus and M. Teres minor showed significantly higher activity at both the $20 \mathrm{Abd}$ and $90 \mathrm{Abd}$ compared with the middle and posterior parts of M. Deltoid and upper parts of $\mathrm{M}$. Trapezius. M. Supraspinatus, the middle and posterior parts of M. Deltoid, and upper and middle parts of M. Trapezius all showed a difference in activity level between the two positions.

These findings suggest that when M. Infraspinatus and M. Teres minor contribute to external rotation as a stabilizer and prime mover, consecutively, M. Supraspinatus, the middle and posterior parts of M. Deltoid, and upper and middle parts of M. Trapezius function according to the positions. Moreover, the activity of the upper and middle parts of $\mathrm{M}$. Trapezius in $90 \mathrm{Abd}$ should influence sta. bilization, adduction and upward rotation of the scapula. Therefore, we conclude that the external rotation position is closely related to shoulder muscle activity and coordination.
\end{abstract}

(Jpn. J. Phys. Fitness Sports Med. 2003, 52: 43 50)

key word : shoulder external rotation, position, EMG, prime mover, stabilizer

\section{I. 緒}

肩の外旋及び内旋といった回旋連動とは，上腕 骨長軸の回旋によって生じる運動である゙”。 た，回旋運動は，肩の運動に伴って上腕骨及び肩 甲骨の位置が変化すなわち運動肢位が变化しても 遂行可能な運動である ${ }^{1-31}$ 。この回旋運動時の 運動肢位の違いは，運動に伴う発揮トルクに影
響し，特に外旋トルクは，肩関節 $90^{\circ}$ 外転位・肘 関節 90 屈曲位で高值を示すことが報告されてい $3^{4.5 !}$.

こ扎に対し，筋電龱学的に回旋運動時の運動肢 位の影響を調べた研究では，静的な筋収縮様式 (Isometric Contraction)による検討 ${ }^{2}$ ６や，肩甲骨 の運動に関! j吉る肩甲骨周团筋の活動までを導出 していない検副てにとどまっている。そのため,

\footnotetext{
1)筑波大学大学院体育科学研究科

Doctoral Program in Health and Sport Sciences, University of 干 305-8574 茨城県つくば㠶上土台1-1-1

2) 筑波大学:体育科学系

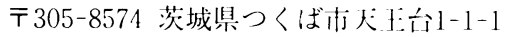

${ }^{3)}$ 水厂赤十字将院

于310-0011 茨城県水戸市三の凡3-12-48

Tsukuba, 1-1-1 Tennodai, Tsukuba-shi, Ibaraki 305-8574. JAPAN Institute of Health and Sports Science. University of Tsukuba, 1-1-1 Tennodai. Tsukuba-shi, Ibaraki 305-8574. JAPAN Mito Red Cross Hospital, 3-12-48 Samnomaru, Mito-shi. Ibaraki 310-0011. JAPAN
} 
運動肢位が肩回旋運動時の筋活動動態にもたらす 影響は，十分明らかになっていると言えない。

また, 回旋運動は, 投球動作 ${ }^{8)}$, 水泳のストロー ク ${ }^{9)}$ に代表されるオーバーヘッドなスポーツ動作 や髪をとかす，上着を着るといった日常生活の 様々な動作 ${ }^{1)}$ 遂行する上で欠くことのできない 運動である。同様に臨床的側面においても，競技

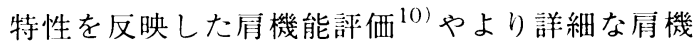
能評価 ${ }^{11)}$ を行うためには, 様々な運動肢位で肩 回旋機能を評価することが重要であると報告され ている，さらに，肩機能の回復及び向上を図るに は，状況に応じて運動肢位を選択して実施してい く必要があると言われている11).

したがって，異なる運動肢位における回旋運動 時の肩周囲各筋の活動動態が解明されれば, 肩機 能の評価, トレーニングプログラム作成等に関わ る有用な基礎資料を提供できると考えられる。

そこでこの課題を解明する…端として, 本研究 では, 回旋運動の 1 つである外旋運動を取り上げ, 2 条件の運動肢位で動的な筋収縮様式 (Concentric Contraction)による外旋運動を行い, 筋電龱 (Electromyography；EMG)によって得られ た肩周囲各筋の活動から外旋運動に対する運動肢 位の影響を検討した。

\section{II. 研 究 方 法}

\section{A. 被験者}

被験者は，全員右利きで左右の肩関節に痛み及 び既往歴を有さず，整形外科医による整形外科的 テストにおいても関節動摇性等の所見を認めなか った肩機能の正常な健常男性 7 名 (年齢24.0 0 1.0 歳, 身長 $172.9 \pm 2.5 \mathrm{~cm}$, 体重 $69.7 \pm 5.5 \mathrm{~kg}$ ) と した。事前に研究の目的と内容を説明し，実験参 加の同意を得た。なお，実験は非利き肩である左 肩で実施した。

\section{B. 実験設定及び運動課題}

本研究の概観を図 1 に示した。運動負荷装置に は，等速性筋出力測定装置 (Cybex 770-NORM, Cybex 社製)を用い，上肢の重量をできる限り排 除するとともにCPM(Continuous Passive Mo.

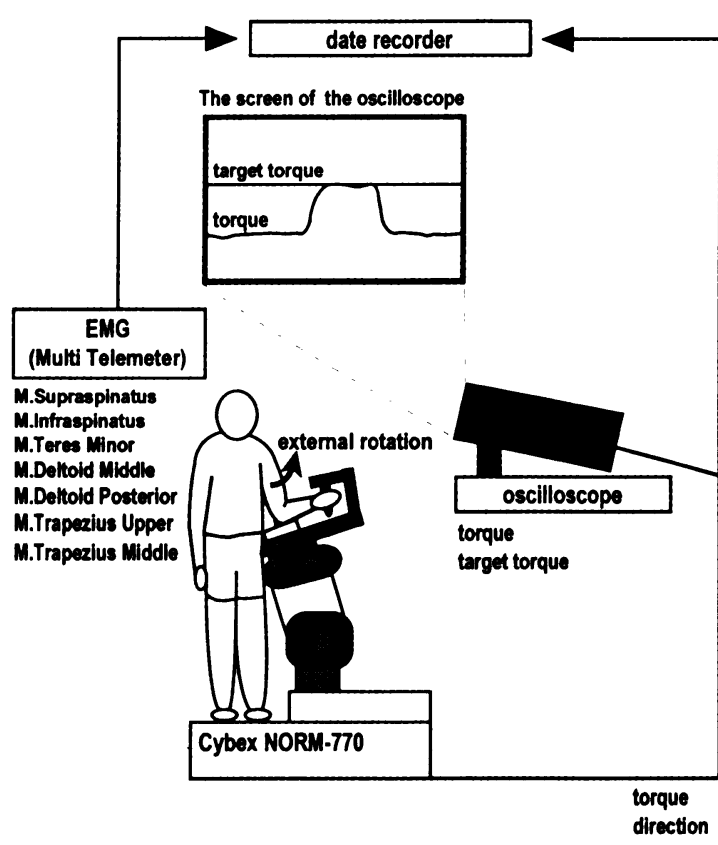

Fig. 1. Experimental set up for recording EMGs, torque, target torque and direction.

tion)モードによって運動スピード $(15 \mathrm{deg} / \mathrm{sec}) を$ 一定に保持した。被験者の前方には, オシロスコー プ(Data SYS 840, Gould 社製)を設置して画面上 に被験者が発揮しているトルクと目標值(ターゲ ットトルク)をカラー表示し，視覚フィードバッ クによってトルクを一定に維持するよう指示し た。

外旋運動時のターゲットトルクについては，先 行研究 ${ }^{12.13)}$ において肩周囲各筋の活動が顕著で あった $15 \mathrm{Nm}$ に設定し, 各運動肢位ともに 5 回 ずつ試行した。また，外旋運動の運動肢位につい ては, 図 2 に示した 20 度外転位 $\left(20^{\circ}\right.$ Abduction； 以下，20 Abd）及び90度外転位 $\left(90^{\circ}\right.$ Abduction； 以下，90 Abd）の 2 条件を設定した。 $20 \mathrm{Abdは,}$ 前腕を回内外中間位，肩関節を Scapula Plane 上 で $20^{\circ}$ 外転，肘関節を $90^{\circ}$ 屈曲し，この肢位を内 外旋中間位として内旋 $60^{\circ}$ 外旋 $30^{\circ}$ の運動角度 で外旋運動を行った．90 Abd は，前腕を回内外 中間位，肩関節を Scapula Plane 上で $90^{\circ}$ 外転, 肘関節を $90^{\circ}$ 屈曲し，この肢位を内外旋中間位と して内外旋中間位～外旋 $90^{\circ}$ の運動角度で外旋運 


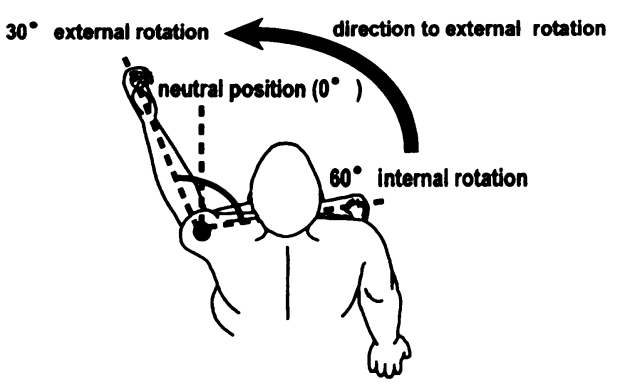

$20^{\circ}$ Abduction (20Abd)

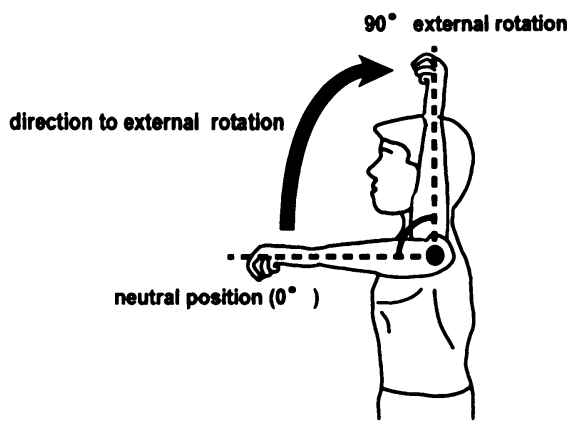

$90^{\circ}$ Abduction (90Abd)

Fig. 2. The basic position used testing.

動を行った。

\section{EMG 及び発揮トルク, 運動角度の記録方} 法

EMG 導出電極には, 直径 $0.05 \mathrm{~mm}$ のワイヤー 電極 (双極貼合わせ電極, インターメディカル社 製) 及び $\mathrm{Ag} / \mathrm{AgCl}$ 表面電極を用いた。被験笳に は，肩周囲各筋の活動特性について検討している 先行研究 $2.6 .12 \sim 15)$, 肩機能を論じた成書 ${ }^{3)}$ 及び 機能解剖学を論じた成書 ${ }^{16)}$ から, 外旋運動への 貢献が大きいと考えられる筋を選択した。被験者 の左肩の棘上筋，棘下筋，小円筋にはワイヤー電 極を挿入し, 三角筋中部線維 (以下, 三角筋中部), 三角筋後部線維 (以下，三角筋後部)，僧帽筋上部 線維 (以下，僧帽筋上部)，僧帽筋中部線維 (以下， 僧帽筋中部)には表面電極を貼付した。電極の貼 付及び挿入位置は Perotto ${ }^{17)}$ の記述に従った。な お，ワイヤー電極の挿入は $22 \mathrm{G}$ のカテラン針を 用いて整形外科医が行い, ワイヤー電極挿入後正 確に挿入されていることを確認するために徒手筋 力検査 (Manual Muscle Testing; MMT)を行って EMG 波形を確認した。生体アンプには，マルチ テレメータ（WEB-5000，日本光電社製）を用い, 時定数 0.03 秒, 高域遮断周波数 $450 \mathrm{~Hz}$ 以上で増 幅後, 各筋の EMG 及び Cybex からの発揮トル ク，運動方向の各出力信号をすべて同期させて データレコーダ(SIR-1000, SONY 社製)に記録し た。

\section{D. 解析処理}

データの解析は，記録したデータをサンプリン グ周波数 $2 \mathrm{kHz}$ で A/D 変換し, 全波整流後, 20 Abd，90 Abd ともに計測した運動角度を $15^{\circ}$ ( 1 秒)ずつ 6 区間に区切り，積分筋電值 (integrated $\mathrm{EMG} ; \mathrm{iEMG}$ )を算出した。各筋の筋活動を比較 検討するため，得られた各筋の iEMG は Kron berg et al. ${ }^{7)}$, Townsend et al. ${ }^{14)}$ 及び Moseley et al. ${ }^{15)}$ の方法を参考に，各筋に対する MMTを最 大努力で実施した際に得られた $\mathrm{iEMG}$ を最大值 (100\%iEMG) として相対值化し，\% $\mathrm{iEMG} と し て ~$ 示した。

\section{$E$. 統計処理}

各筋の \% $\mathrm{iEMG}$ は, 平均值士標準偏差で表した。 また, 得られた各筋の \% iEMG を比較するために， 各運動肢位の運動角度ごとに分散分析を行い，F 值の有意であった運動角度に関してFisher's PLSD 法による多重比較を行った。なお，統計処 理の有意水準は, $5 \%$ 末満とした。

\section{III. 結 果}

\section{A. 20 Abd における各筋の \% $\mathrm{iEMG}$}

図 3 は, $20 \mathrm{Abd}$ の代表值として $(\mathrm{A})$ 内旋 $45^{\circ}$ $30^{\circ}$, (B) 内旋 $15^{\circ} \sim$ 内外旋中間位, (C) 外旋 $15^{\circ} \sim$ $30^{\circ}$ の各運動角度における各筋の \% $\mathrm{iEMG}$ を示し たものである.

回旋筋腱板を構成する棘上筋，棘下筋，小円筋 

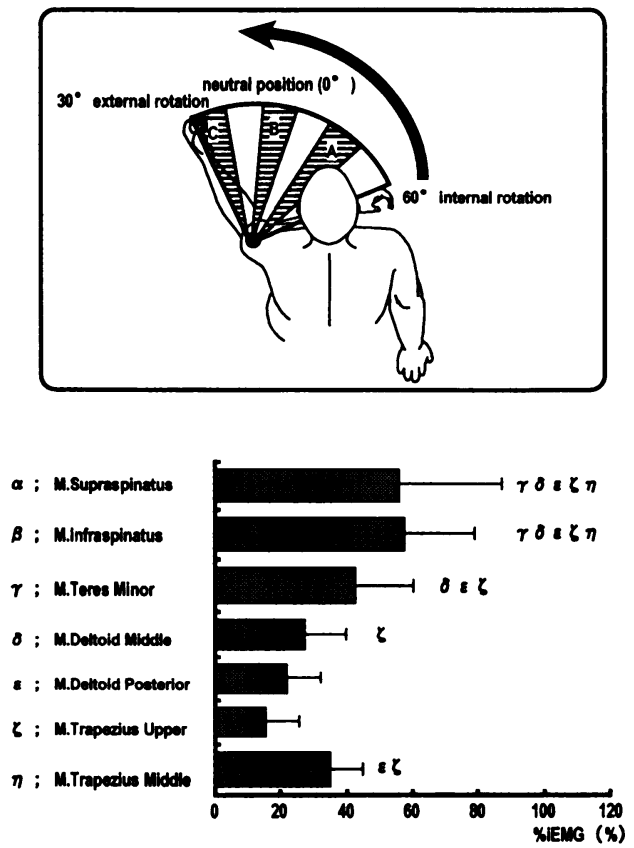

(B) $1^{\circ}$ internal rotation $\sim$ neutral postion

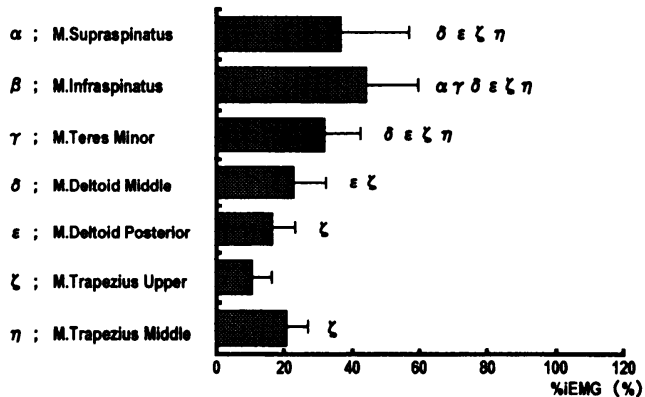

(A) $45^{\circ}$ internal rotation $\sim 30^{\circ}$ internal rotation

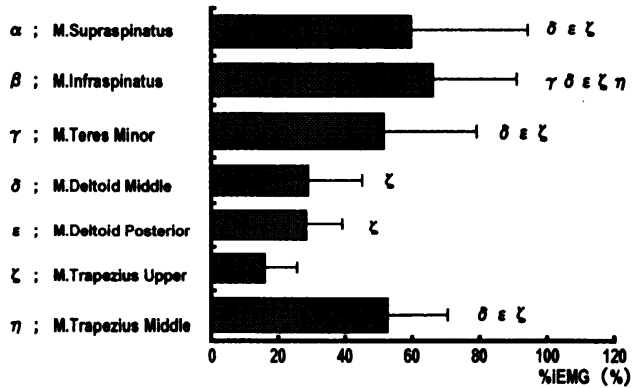

(C) $15^{\circ}$ external rotation $\sim 30^{\circ}$ external rotation

Fig. 3. Comparison of \%iEMG between shoulder muscle at $20^{\circ}$ Abduction $(20 \mathrm{Abd}) \mathrm{dur}$. ing external rotation. (A) $45^{\circ}$ internal rotation $-30^{\circ}$ internal rotation. (B) $15^{\circ}$ internal rotation $\sim$ neutral position $(C) 15^{\circ}$ external rotation $\sim 30^{\circ}$ external rotation are repre sentative of the external rotation angles. Greek in the right side of the error bar means significant with the Greek in the column. As to “(A) $\eta$ : M. Trapezius Middle”, M. Trapezius Middle was significantly higher compared with M. Trapezius $(\zeta)$. Statistical significance was accepted at $\mathrm{p}<0.05$. Values are mean $\pm \mathrm{SD}$.

の\%iEMG は，すべての運動角度において三角筋 中部，後部及び僧帽筋上部の \% ${ }_{\mathrm{i}} \mathrm{MGG}$ と比較して 有意に高い值を示した $(\mathrm{p}<0.05)$. 棘下筋と棘上 筋の \% $\mathrm{iEMG}$ を比較すると，咪下筋の \% $\mathrm{iEMG}$ は 内旋 $45^{\circ} \sim 30^{\circ}$ の運動角度で棘上筋の \% $\mathrm{iEMG}$ りも高值を示したが, 内旋 $30^{\circ}$ 位からの外旋範囲 ではほほ同程度の％iEMG を示した。一方，梀下 筋と小円筋の \% $\mathrm{iEMG}$ を比較すると，棘下筋の \%iEMGがすべての運動角度において有意に高い 值を示していた $(\mathrm{p}<0.05)$.

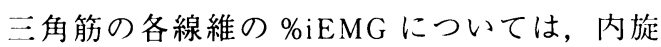
$60^{\circ} \sim 30^{\circ}$ の運動角度において三角筋中部の $\% \mathrm{iEMG}$ が三角筋後部の \% $\mathrm{iEMG}$ と比較して有意 に高い值を示していた $(\mathrm{p}<0.05)$.

僧帽筋中部の \% $\mathrm{iEMG}$ は, 内旋 $15^{\circ}$ 位からの外 旋範囲において三角筋後部，僧帽筋上部の
$\% \mathrm{iEMG}$ と比較して有意に高く, 内外旋中間位 らの外旋範囲では，三角筋中部の \% $\mathrm{iEMG}$ と比較 して有意に高い値を示した $(\mathrm{p}<0.05)$.

\section{B. $90 \mathrm{Abd}$ における各筋の \% iEMG}

図 4 は, $90 \mathrm{Abd}$ の代表值として (A)内外旋中 間位 $\sim$ 外旋 $15^{\circ}$, (B) 外旋 $30^{\circ} \sim 45^{\circ}$, (C) 外旋 $60^{\circ} \sim$ $75^{\circ}$ の各運動角度における各筋の $\% \mathrm{iEMG}$ を示し たものである。

棘上筋, 棘下筋の \% iEMG はすべての運動角度 において，小円筋の \% iEMG は外旋 $60^{\circ}$ 位までの 外旋範囲において，三角筋中部，後部及び僧帽筋 上部の \% ${ }_{\text {iEMG }}$ と比較して有意に高い值を示した $(\mathrm{p}<0.05)$. 回旋筋腱板の \% $\mathrm{iEMG}$ については, 棘下筋の \% ${ }^{\mathrm{E} E M G}$ がすべての運動角度において棘 上筋及び小円筋の \% $\mathrm{iEMG}$ と比較して有意に高い 

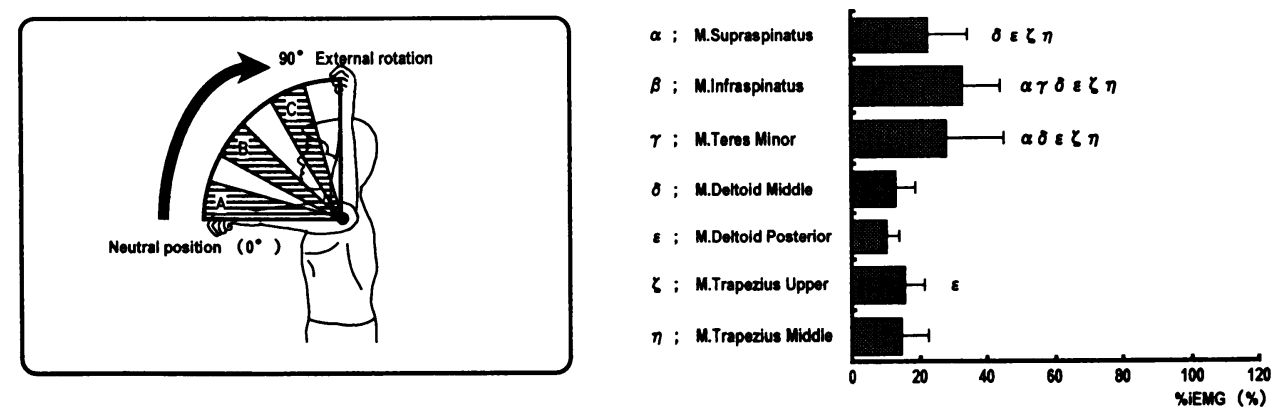

(A) Neutral postion $\sim 15^{\circ}$ External rotation
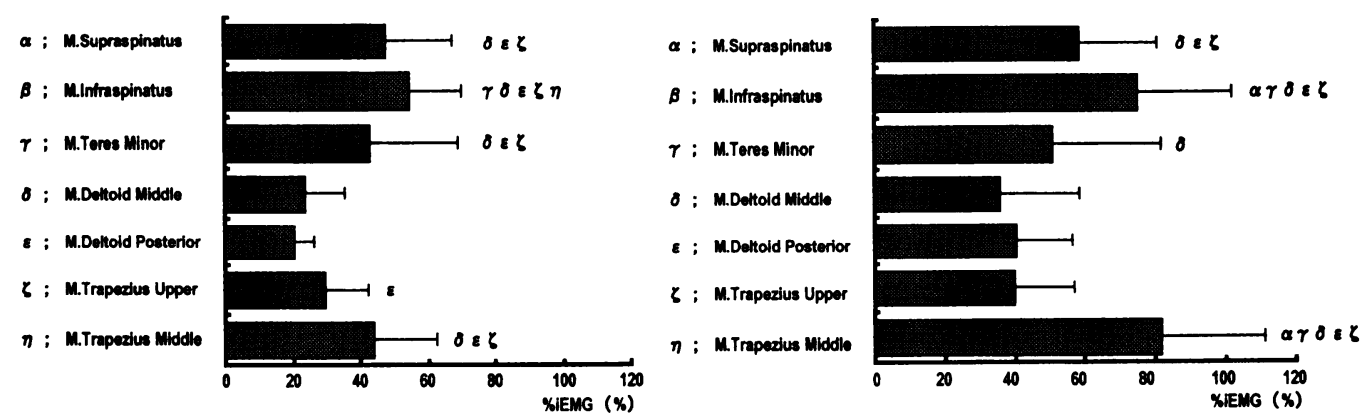

(B) $30^{\circ}$ External rotation $\sim 45^{\circ}$ External rotation

(C) $60^{\circ}$ External rotation $\sim 75^{\circ}$ External rotation

Fig. 4. Comparison of \%iEMG between shoulder muscle at $90^{\circ}$ Abduction (90 Abd) dur ing external rotation. (A) neutral position $\sim 15^{\circ}$ external rotation. (B) $30^{\circ}$ external rotation $\sim 45^{\circ}$ external position and $(C) 60^{\circ}$ external rotation $\sim 75^{\circ}$ external rotation are representative of the external rotation angles. Greek in the right side of the error bar means significant with the Greek in the column. As to "(A) $\zeta$; M. Trapezius Up per", M. Trapezius Upper was significantly higher compared with M. Deltold posterior $(\varepsilon)$. Statistical significance was accepted at $p<0.05$. Values are mean \pm SD.

値を示した $(\mathrm{p}<0.05)$.

また，僧帽筋中部の \% iEMG は外旋 $15^{\circ}$ 位から の運動範囲において，三角筋の各線維及び僧帽筋 上部の \% $\mathrm{iEMG}$ と比較して有意に高い值を示した $(\mathrm{p}<0.05)$. 一方，僧帽筋中部の \% $\mathrm{iEMG}$ と回旋 筋腱板の \% iEMG を比較すると, $20 \mathrm{Abd}$ での活 動動態と異なり，外旋 $45^{\circ}$ 位からの外旋範囲にお いて小円筋の \% $\mathrm{iEMG}$ より, 外旋 $60^{\circ}$ 位からの外 旋範囲において棘上筋，棘下筋の \% $\mathrm{iEMG}$ より有 意に高い值を示した $(\mathrm{p}<0.05)$ 。同様に, 僧帽筋 上部の \% $\mathrm{iEMG}$ も $20 \mathrm{Abd}$ での活動動態と異な $り$ ，三角筋中部，後部の \% $\mathrm{iEMG}$ と比較して同程 度の \% iEMG あるいは有意ではないものの高い \%iEMG を示した。

\section{N. 考察}

本研究の目的は, $20 \mathrm{Abd}, 90 \mathrm{Abd}$ の 2 条件の 運動肢位による外旋運動を行い, 肩周囲各筋の \% $\mathrm{iEMG}$ から外旋運動における運動肢位の影響を 検討することであった。

回旋筋腱板を構成する棘上筋，棘下筋，小円筋 の 3 筋の活動は, $90 \mathrm{Abd}$ の僧帽筋中部の活動を 除いて両運動肢位とも他の肩周囲各筋の活動と比 較して有意に高い値を示していた(図 $3 ， 4$ )。し たがって，この 3 筋の活動はこれまで報告されて いるとおり，上腕骨頭の前方移動を減らす肩甲上 腕関節の安定化機構 (stabilizer) として機能する とともに，外旋運動遂行にも大きく関与している と考えられる2 $23,7,16,18,19)$. 
一方，外旋運動遂行に対するこの 3 筋の協調動 態については，十分明らかになっていない。そこ で，この 3 筋の協調動態について，3筋の中で最 も高值を示した棘下筋を中心に検討する．棘下筋 と小円筋の \% $\mathrm{iEMG}$ は運動肢位による活動の相違 を認めなかったが，両肢位ともに棘下筋の活動は 小円筋の活動と比較して有意に高い值を示した (図 3，4). 小円筋は棘下筋と同様に外旋運動の 主働筋 (prime mover) として考えられている筋で あるため ${ }^{2,3,16,20)}$, Jenp et al. ${ }^{2)}$ の報告やColachis \& Strohm ${ }^{20)}$ の報告と同様に棘下筋と小円筋 とが同程度の活動を示し, “functional unit”を形 成して外旋運動遂行に関与するものと予想された が，完全な一致を見なかった。両筋の神経支配は 棘下筋が肩甲上神経，小円筋が腋窩神経と異なっ ており ${ }^{3,16)}$, 筋長, 生理的横断面積 (Physiological Cross-Sectional Area; PCSA)及び potential moment も両筋で異なる ${ }^{21)}$. そのため, これらの要因が \% $\mathrm{iEMG}$ の顕著な差をもたらした と考えられる。したがって，棘下筋と小円筋は， 完全な “functional unit” として外旋運動に関与 していると言うよりむしろ，異なる活動によって 協調動態を保ちながら外旋運動に作用していると 考えるべきではなかろうか.

続いて,棘下筋と棘上筋の協調動態を検討する. 棘上筋の機能については，先に述べた stabilizer

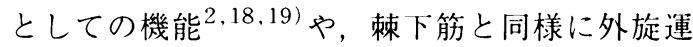
動の prime mover として作用しているとの報告 ${ }^{7)}$ がある．本研究の結果，90 Abdにおける棘上筋 の活動は棘下筋の活動と比較して有意に低い値を 示していたが，20 Abd では両筋が内旋 $30^{\circ}$ 外旋 $30^{\circ}$ の運動角度においてほぼ同程度の活動を示し ていた(図 3，4)。そのため, 棘上筋の機能は運 動肢位や運動角度によって变化し, 特に $20 \mathrm{Abd}$ では prime mover として作用している可能性が ある。しかしながら，棘上筋の回旋運動への貢献 には，回旋軸と棘上筋長軸との位置関係 ${ }^{7.22)}$ も 影響しており，例え両筋の \% $\mathrm{iEMG}$ が同程度であ っても，同等の役割を果たし，外旋運動の prime mover として機能していると言い切ることは難し い.いずれにしても，棘上筋の機能は運動肢位や
運動角度によって異なってくる可能性が示唆され た。この筋の機能ついては, 今後, さらに検討し ていく必要があるだろう.

三角筋後部の活動は，両運動肢位ともに回旋筋 腱板の活動よりも低く, 先行研究と同様の結果を 示した (図 $3 ， 4)^{2,7,13,14)}$. 三角筋後部の機能 については, 外旋運動の prime mover を補助す る筋(assistant mover) としての報告 ${ }^{3.16)}$ の他に, 棘上筋とともに上腕骨頭の安定化を図る stabilizer として作用するとの報告 ${ }^{2,7)}$ も見られる。し たがって，三角筋後部も貢献度こそ回旋筋腱板の 各筋より低いものの, 運動肢位に関わらず外旋運 動遂行に関与するとともに関節の安定化にも作用 するものと推察される。また, Kronberg et al. ${ }^{7)}$ やPoppen \& Walker ${ }^{23)}$ は, 三角筋後部の stabilizer 機能が肩外転角度の増大に伴って高まるこ とを報告しているが，本研究では三角筋後部の活 動に運動肢位に対応した変化を認めなかった(図 3，4).しかしながら，三角筋後部そのものの 機能は運動肢位に応じて変化している可能性が高 く，特に $90 \mathrm{Abd}$ では, stabilizer 機能すなわち 関節安定化に結びつく活動が増大したものと推察 される。

-一方， $20 \mathrm{Abd}$ の三角筋中部の\%iEMGは, 内旋 $60^{\circ} \sim 30^{\circ}$ の連動角度で三角筋後部の活動と比較し て高值を示していた(図3)。これまでに，三角筋 中部を外旋運動に関与する筋として位置付けてい る記述はほとんど見当たらない24)。しかし, 三 角筋中部の筋線維の一部分は肩峰背側に向かって いることから外旋運動への関与を否定することは できない。したがって，三角筋中部も $20 \mathrm{Abd} に$ おいて外旋運動に貢献している可能性があるもの と推察される。

ここまで肩甲骨と上腕骨に起始と付着を持つ筋 の活動について検討してきたが，これから体幹と 肩甲骨に起始と付着を持つ僧帽筋上部, 僧帽笳中 部の活動について検討していきたい，僧帽筋上部 及び中部は，ともに90 Abdにおいて顕著に活動 していた(図 4 )。僧帽筋は, 肩甲胸郭関節の安定 化及び運動に作用する肩甲骨周囲筋であり，僧帽 筋上部は肩甲骨の挙上や上方回旋に，僧帽筋中部 
は肩甲骨の内転に作用すると言われている 3.15.16). したがって，90 Abd で見られた僧帽筋 上部, 中部の顕著な活動の増大が, 肩甲督安定化 の作用や上方回旋及び内転連動の方向性に変化を もたらし，肩甲骨を肩甲上腕関節の安定に最も適 した位置へ移動させていると考えられる。

以上のように，外旋運動の prime mover と位 置付けられる棘下筋や小川筋の活動については, 運動肢位による違いを認めなかった。一方，棘上： 筋や三角筋中部及び後部の機能は連動肢位に対応 して変化するものと推察され，肩甲骨の運動に関 わる僧帽筋上部及び中部も運動肢位による活動の 違いを認めた。したがって, 棘下筋, 小円筋が運 動肢位に関わらず外旋運動の prime mover とし て機能するために，棘上筋，三角筋及び僧帽筋の 各筋は，運動肢位に応じて活動動態や各筋との協 調動態を変化させ，外旋運動遂行及び肩甲上腕関 節，肩甲胸郭関節の安定化に作用していると考え られた。

\section{V. と め}

本研究では，肩関節に既往歴及び関節動摇性の ない健常男性を対象として 2 条件の運動肢位(20 $\mathrm{Abd}, 90 \mathrm{Abd}$ )による外旋運動を行い, 屃周囲各 筋の活動動態から外旋運動時の運動肢位の影響に ついて検討した。

その結果，棘下筋，小円筋は運動肢位に関わら ず肩甲上腕関節の安定化を図る stabilizer として 機能するとともに, prime mover として運動の中 心的役割を果たしていると考えられた。棘.上.筋， 三角筋後部も stabilizer として作用するとともに 運動遂行にも関与し, 両者の機能は運動肢位に対 応して変化していく可能性が示唆された。三角筋

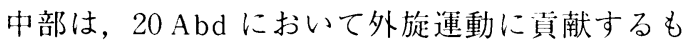
のと推察された．僧帽筋上部及び中部については 90 Abd で顕著に活動し，その活動は肩甲骨安定 化の作用や肩甲骨の連動の方向性に大きく影響し ていると考えられた。これらのことから, 棘下筋, 小円筋が運動肢位に関わらず外旋運動の prime mover として機能するために, 棘上筋, 三角筋及 び僧帽筋の各筋が外旋運動の運動肢位に対応して
活動動態や各筋との協調動態を変化させていると 考えられた。

肩機能の評価やトレーニングプログラム作成に 当たって，肩機能を司っている筋の機能や協調動 態を多角的に評価し，より効果的なトレーニング 肢位で強化をすることが望ましいと言われてい る。その中に拈いて本研究で得られた知見は，よ り最適なトレーニング肢位を選択する上での一助 となると考えられる，今後さらに，肩周囲筋の活 動動態に関する知見を深めていくために運動肢位 のみならず様々な運動課題を設定し，より詳細な 検討を加えていくことも必要であろう.

\section{(受理月 平成14年10月21日)}

\section{参 考 文 献}

1) Kapandji I. A. (荻島秀男監訳, 嶋田智明訳)，カパ ンディ関節の生:理学 (I) 上肢, 医秚薬出版株式会 社, 束京, (1992)

2) Jenp Y-N., Malanga G. A., Growney E. S., An K-N. Activation of the rotator cuff in generating isometric shoulder rotation torque. Am. J. Sports Med.. (1996), 24. 477-485.

3）信原克哉. 肩一その機能と臨床一，第 3 版，局の バイオメカニクス，炎学書院，東京，(2001)，4888.

4) Greenfield B. H., Donatelli R., Wooden M. J., Wilkes $J$. Isokinetic evaluation of shoulder rotational strength between the plane of scapula and the frontal plane. Am. J. Sports Med., (1990), 18, 124-128.

5) Soderberg G. J., Blaschak M. J. Shoulder internal and external rotator peak torque production through a velocity spectrum in differing positions. J. Orthop. Sports Phys. Ther., (1987), 8, 518-524.

6) Blackburn T. A., McLeod W. D., White B., Wofford L. EMG analysis of posterior rotator cuff exercises, (1990), Athl. Train., 25, 40-45.

7) Kronberg M., Nemeth G., Brostrom L. Muscle activ. ity and coordination in the normal shoulder An electromygraphic study. Clin. Orthop., (1990), 257. 76-85.

8) Pappas A. M., Zawacki R. M., Sullivan, T. J. Biomechanics of baseball pitching A preliminary report. Am. J. Sports Med., (1985), 13, 216-222.

9) Pink M., Perry J., Browne A., Scovazzo M. L., Kerrigan J. The normal shoulder during freestyle swim. ming An electromyographic and cinematographic analysis of twelve muscles. Am. J. Sports Med.. (1991), 19, 569-575.

10) Wilk K. E., Andrews J. R., Arrigo C. A., Keirns M. A., Erber D. J. The strength characteristics of inter- 
nal and external rotator muscles in professional baseball pitchers. Am. J. Sports Med., (1993), 21. 61-66.

11）山口光图, 筒井廣明, アスレチックリハビリテー ションの進歩一肩を中心として一，（1999），体育 の科学, 49, 647-654.

12）木塚朝博, 山口晴信, 高松薫, 肩の低負荷トレー ニングとして有効な負荷範井と動作角度範囲の検 討, バイオメカニズム, (2000)，15，213-223.

13）鈴木徳年，木塚朝博，埜口博司，田中忍，下條 仁士, 白木 仁, 向井直樹, 宮永 豊, 肩外旋運 動時の負荷量の変化に伴う肩周囲筋群の活動特性, 体力科学, (2000)，49，481-494.

Suzuki N., Kizuka T., Noguchi H., Tanaka S., Shimo. jo H., Shiraki H., Mukai N., Miyanaga Y. Electromyographic analysis of shoulder muscles during shoulder external rotation with reference to load magnitude. Jpn. J. Phys. Fitness Sports Med., (2000), 49, 481-494 (in Japanese)

14) Townsend H., Jobe F.W., Pink M., Perry J. Elec. tromyographic analysis of the glenohumeral muscles during a baseball rehabilitation program. Am. J. Sports Med., (1991), 19, 264-272.

15) Moseley J. B., Jobe F. W., Pink M., Perry J., Tibone J. EMG analysis of the scapular muscles during a shoulder rehabilitation program. Am.J.Sports Med., (1992), 20, 128-134.

16）中村隆一, 齋藤 宏. 基礎運動学, 第 5 版, 四肢 と体幹の運動, 医歯薬出版株式会社, 東京, (2000),
190-197.

17）Perotto A. O. (田島達也監訳)，筋電困のための解剖 ガイド一四肢・体幹一, 第 3 版, 西村書店, 東京, (1985)

18) Cain P. R., Mutschler T. A., Fu F. H., Lee S. K. Anterior stability of the glenohumeral joint A dynamic model. Am.J.Sports.Med., (1987), 15, 144-148.

19) Leẹ S-B., Kim K-J., O'Driscoll S. W., Morrey B. F. An $\mathrm{K}-\mathrm{N}$. Dynamic glenohumeral stability provided by the rotator cuff muscles in the mid-range and end-range of motion A study in cadavera. J. Bone Joint Surg., (2000), 82-A, 849-857.

20) Colachis S. C., Strohm B. R. Effect of suprascapular and axillary nerve blocks on muscle force in upper extremity. Arch. Phys. Med. Rehabil., (1971), 52. 22-29.

21) Keating J. F., Waterworth P., Shaw-dunn J., Crossan J. The relative strengths of the rotator cuff muscles A cadaver study. J. Bone Joint Surg., (1993), 75-B, 137-40.

22) Ihashi K., Matsushita N., Yagi R., Handa Y. Rota. tional action of the supraspinatus muscle on the shoulder joint. J. Electromyogr. Kinesiol., (1998), 8. 337-346.

23) Poppen N. K., Walker P. S. Forces at the glenohumeral joint in abduction. Clin. Orthop., (1978), 135, 165-170.

24）河上敬介, 磯貝 香, 骨格筋の形と触察法, 初版, 上肢の筋, 大峰閣, 熊本, (1998)，151-157. 